\title{
An Overview And Critical Evaluation Of Financial Reform System In China
}

Mohamad Sepehri, (E-mail: msepehr@ju.edu), Jacksonville University

\begin{abstract}
The purpose of this survey study has been to identify the primary elements of the financial sector reform (FSR) and their impact on the socioeconomic environment of China (People's Republic of China), and to assess the level of progress, risks, and problems stemming from the China's political economy. The research findings indicate that the level of the financial risks has greatly increased in recent years and that China is dealing with inherent financial concerns and potential financial crisis. Ironically, the growth of foreign direct investment has accelerated in Chinese ventures (Warner, 2004), in spite of the recent warnings by various sources such as Business Week (January 19 \& May 3, 2004). Currently, the amount of foreign direct investment - about $\$ 491$ billion - is flooding the foreign currency system and putting heavy pressure on the Yuan. This is because the investors usually rely heavily on the financial ratios i.e. profitability and growth, as the criteria for investment decisions. However, it would be a critical mistake to disregard the role of "policy" in risk analysis especially in a political economy such as China. This research study intends to establish an accurate barometer for the assessment of the risk factors within the financial sector and their impact on sector's reform.
\end{abstract}

\section{STANDARD OBJECTIVES OF FINANCIAL SECTOR REFORM}

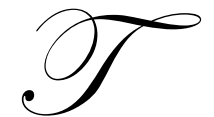

he success of the reform policies that govern the financial sector can be measured against several standard objectives of the financial sector reform. The first and foremost is the maintenance of stability, a charge that not only includes an awareness of the macro-economic dynamics, but the political and social dynamics as well (Wei, 1-2). The other objectives are mutually desirable within the reform process. They are: (a) an improvement of the functionality and performance of a market-driven supply, demand, and price system; (b) an enabling of investment consideration with respect to asset class, risk, scale, and maturity; and (c) the promotion of an economic environment wherein efficient movement and allocation of capital is rewarded.

\section{Improving the Performance of the Market-Driven Supply, Demand, and Price System}

A major obstacle to financial sector reform is the distortion caused by government involvement in ownership, management, and planning of the vital sectors. A necessary element of a market-driven system is the improvement of the "structural, regulatory, [and] informational [infrastructure]" (Mathieu, 1). The performance of a market-driven financial sector depends on the availability and the quality of the information as well as the timing of reform policies to strengthen the critical aspects of the financial sector (Mathieu, 5).

\section{Consideration of Asset Class, Risk, Scale, and Maturity}

When state owned banks in command economies behave as policy lenders, they set targets for growth, production, and consumption which, in turn, provide impetus for the state owned banks to supply the necessary capital requirements to meet the expected targets. It should be noticed that bad lending decisions are not exclusively a product of state ownership; rather, the commercial bank failures can be traced to the loopholes of the financial systems that are often exploited for questionable lending practices. 


\section{Promotion of Efficient Movement of Allocation of Capital}

The costs, risks, and institutional solvency would determine the level of financial liquidity in a system. However, the positive measures of financial system liquidity and macro economic growth are not the ultimate determinants of future economic strength. They represent only two of the dimensions of the total equation, while the third dimension - policy reform - should also be included in this picture. As seen in the Asian financial crisis, policies that are financially crippling can co-exist within a vibrant macro-economic environment (Mathieu, 4).

\section{HISTORICAL ELEMENTS OF CHINA'S FINANCIAL SECTOR}

Throughout the early 1990s, many state owned banks were converted to "private" commercial banks. Consequently, the People's Bank of China (PBC) enacted policy that brought these commercial banks under the supervision of the state-owned banks (SOB). In practice, the SOBs were made similar to the Federal Reserve branch banks of the U.S. Federal Reserve system. (Lardy, 62-63) Increasingly, the PBC has engaged in executing monetary objectives through instruments of indirect control - interest rate control, overnight lending rates, open market operations, and reserve ratio requirements. (IMF, 1996) This evolution resulted in the creation of policy banks like the China Agricultural Development Bank (CADB) to aid in supporting areas on industry identified as strategic or vital. Such a move, to include the CADB as a policy bank, reflects the priority that the Chinese Communist Party assigns to agriculture. (Lardy, 62, 177)

The separation of policy lending from other lending activities was a crucial step toward the presumed endgoal of the PBC, to strengthen the asset quality of SOBs so that they may be brought forward for future public offerings. (Roberts, 2004) In recent years, the PBC has used its substantial reserves to write off ¥644 billion of policy loans, while taking steps to isolate the incurrence of future policy lending failures to institutions directly under the control of the Ministry of Finance. (Lardy, 176-9)

The presence of foreign banks in China is allowed only under very strict guidelines. (Ross, 2002) The functions of these banks have been highly regulated with regard to foreign currency exchange. As a result, neither Chinese businesses nor Chinese households may engage in any banking relationship with a foreign-owned bank. At present, the foreign bank assets account for only 1.5 to 2.5 percent of total bank assets in China - a level that has remained stagnant since the mid-1990s. (Lardy, 125) Private ownerships of Chinese banks are virtually non-existent in China. Of all the banks, only the Shenzhen Development Bank is listed on a public exchange and only the China Minsheng Bank is a legal private bank. (Lardy, 65)

In sum, China's financial system is indirectly controlled by the central bank - the People's Bank of China through monetary tools such as interest rate bands, open market operations, and required reserve ratios. The job of monitoring regulatory authority belongs to state-owned banks, which have direct supervisory control over policy and foreign banks. The PBC and the Ministry of Finance maintain direct control over policy and foreign banks; while private and non-banking institutions are supervised along with the commercial banks by the SOBs. Together, these efforts at re-organization and the specific assignment of responsibility have helped to prepare China's financial sector for the inevitable changes in the process of financial sector liberalization.

\section{CONCERNS AND ISSUES REGARDING CHINA'S FINANCIAL SECTOR REFORM}

This paper will focus on three significant areas of reform concerning China's financial sector. The outcome of the policies that govern these areas will serve as the barometer for the level of strength and the dynamism with which the Chinese economy will meet future challenges.

\section{Interest Rate Liberalization}

Perhaps, the most significant sign of reform will be reflected in the process of liberalizing the interest rates. In China's case, the task is much more complex and prone to failure as there are literally hundreds of different rates being set on a periodic basis by the PBC. (Wei, 105) 
To understand and to explain this process further, three critical areas will be explored:

\section{The Role of the Central Bank in Determining the Interest Rates}

In China, commercial banks are allowed a measure of freedom in determining certain rates. For instance, the central bank sets a "reference rate" for each loan rate from which a proprietary floating margin of twenty percent is allowed. (Wei, 105)

The People's Bank of China is failing by traditional monetarist standards in transitioning away from the old system of using the financial sector as a conduit of liquidity for the purpose of keeping enterprises solvent to the new standard which relies upon interest rates - the cost of capital - to determine the availability of capital within the financial system. Central bank lending to state and commercial banks is often for the purpose of funding continuing operations of enterprise - paying worker salaries and material purchases, rather than capital expenditures or investment. (Lardy, 43) In practice, the attempt of the central bank to set the interest rates seem to be meaningless so long as the capital spigot of the central bank is left open to any enterprise that is experiencing an operational shortfall, regardless of risk or credit structure.

The action of the central bank can be defined as the granting of "policy loans." These loans, provided at a favorable or subsidized rates - in comparison to loans made to the non-public sector - will continue to weaken any attempt to transition to a more indirect method of monetary control over savings and investments. Since the central bank's direct intervention in the credit market has driven twenty-seven percent of the economy away from any meaningful system of monetary control, the $\mathrm{PBC}$ has no meaningful control to stimulate this portion of the economy in the event of recession, nor the power to control excessive growth. Moreover, as the reliance on internal financing increases, growth in deposits may fall, forcing the state and commercial banks to seek government capital which may cause more pressure on deficits.

In short, the central bank's "dual-standard" with regard to expansion/contraction of the money supply is dangerously undermining the continued health of the state and commercial banks as well as the PBC's ability to enact meaningful current and future monetary policies.

\section{Interest Rate Policy on Deposits}

One of the most impressive statistics often reported with regard to China's financial system is the exceptional level of savings remitted to the banks by households. According to the IMF: International financial Statistics (March 2004, 278), at the end of the first quarter of 2003, China's household savings deposits totaled $¥ 8,660.58$ billion RMB, or between $\$ 1.0$ and $\$ 1.33$ trillion USD - increasing at an annual rate of nearly 16 percent since 1997. (IMF:IFS, 2004; Roberts, 2004) This statistic has often been used as a measure of financial health; however, China's high savings rate and the level of savings reflect a different picture - a shallow financial system, constrained to very few options of capital investment. (Aziz \& Duenwald, 4)

China's households are enjoying an annual increase in disposable income of 8.2 percent in urban areas and about 6.4 percent increase among rural households. Reforms within the state enterprise sector and the lack of a social insurance system have raised concerns regarding the future employment and income streams, while the depositing of funds within banks remain the primary mode of savings.

The process of socioeconomic transformation within China has been and is a substantial motivation for the growth of savings - savings are not accumulating due to interest income sensitivity, which is the desires reason. Moreover, through indirect means, the People's Bank of China is promoting the misuse of these deposits. The government mandated interest paid on savings, gives states and commercial banks little encouragement to re-invest deposits in low-risk, short-term investment instruments. The result is a propensity toward the severe mismanagement of capital, as banks seek higher profits through risk bearing loan activity since the PBC has been slow to reduce deposit rates. (Wei, 104) 
Interest Rates

IMF: IFS (March 2004) 1997 - 2002

\begin{tabular}{llllllll}
\hline & & & & & & \\
& $\mathbf{1 9 9 7}$ & $\mathbf{1 9 9 8}$ & $\mathbf{1 9 9 9}$ & $\mathbf{2 0 0 0}$ & $\mathbf{2 0 0 1}$ & $\mathbf{2 0 0 2}$ & \\
\hline Government Bond Rate & 8.55 & 4.59 & 3.24 & 3.24 & 3.24 & 2.70 \\
Deposit Rate & 5.67 & 3.78 & 2.25 & 2.25 & 2.25 & 1.98 & 5.31 \\
Lending Rate & 8.64 & 6.39 & 5.85 & 5.85 & 5.85 & 0.72 \\
Risk Free Margin of Profit & 2.88 & 0.81 & 0.99 & 0.99 & 0.99 & 3.33 \\
Margin of Profit w/Risk & 2.97 & 2.61 & 3.60 & 3.60 & 3.60 & \\
\hline
\end{tabular}

The liberalization of deposit rates may indeed result in a steep drop in growth of deposits - a prospect that PCB fears may impede future growth (Aziz \& Duenwald, 5); however, the inability of the state and commercial banks to match incoming deposits with the availability of "bankable projects" undermines the fiduciary responsibility of maintaining those deposits and ensuring a profitable operation. (Gregory, 2001) On January $1^{\text {st }}$ of 2004, the PBC did enact a measure of liberalization of deposit rate determination - in the form of a deposit rate "band" (a margin set to a reference rate similar to that applied to loan rates) - an initial move toward total proprietary control over deposit rates that will greatly serve to strengthen both the asset classes and operational profitability of the state and commercial banking sector. (Roberts, 2004)

Interest Rate Policy on Rentable funds

A number of issues need to be addressed:

a) Inter-Bank Loans: Although the PBC does set the interest rate at which the state and commercial banks may offer overnight loans to other banks, the oversight authority of this particular area of the financial system has virtually been abandoned since January 1, 1996. (Wei, 106) Inter-bank loans are perhaps the most abused source of capital, as they are often used to cover shortfalls in cash for longer than their intended overnight duration.

Examination of the PBC's use of interest rate policy, combined with lack of any effective policy to change the pace of economic activity, may suggest that China's required reserve ration policies have and will be the preferred means of effective control of financial lending

b) Rent to Enterprise and Soft Budget Constraints: State owned enterprise consumes about ninety percent of the rentable funds in China, but produces only slightly more than fifty percent of the GDP. (Heytens \& Karacadag, 2001) An analysis of the financial soundness of state-owned enterprise reveals a systematic competitive weakness as a consequence of over-hiring, outdated cost-inducing capital goods, and the heavy burden of social responsibility for housing, health, and food for workers. (Heytens \& Karacadag, 2001)

Due to the weakness of the projects to which funds are loaned, most lending institutions ignore risk, inflation, investment feasibility, and project maturity factors.

The privatization of commercial banks and the liberalization of lending rates must first be preceded by reforms to curb the practice of allowing state-owned enterprise to run soft budgets. The failure to stop the use of soft budgets before the aforementioned reforms will result in the cost of rents being positively correlated to increase in demand for rentable funds. The inability to meet debt servicing requirements could lead into widespread calls on loans, bankruptcies across all borrowing classes (as cost of rents would rise for all borrowers), and bank failures.

c) Term Structure of Rents: The mandate by the PBC that loans not to exceed one year in maturity, combined with the issues discussed previously (in "a" and "b"), presents yet another challenge to the health of China's financial system (Wei, 104) The typical Chinese firm fits the category of a highly leveraged firm, 
as its debt is structured entirely of short-term debt with a maturity of one-year or less. Moreover, the fluctuation of a firm's current account level is often tied to business cycles and since Chinese bank lending is segregated among economic sectors (i.e. Bank of Agriculture, Bank of Construction), the one-year maturity mandate may not coincide with all business cycles - and times of high cash flow. Therefore, both the term structure of rents and the probable rise in the cost of rents (due to soft-budget demands) establishes the setting for a potentially volatile transition toward a liberalized financial sector.

A move toward liberalization of the lending rate, without first reforming the use of loans for budget shortfalls, would result in many firms becoming insolvent and defaulting on their loans. (Feltenstein \& Nsouli, 5-6 \& 15; Wei, 155-7) However, regardless of PCB's current intentions, the process of transition requires an examination of proper sequencing options of liberalization in order to maintain social and macro-economic stability.

\section{Sequencing of Interest Rate Liberalization: Policy Options}

Two distinct policy options: a) "loan rate in advance" and b) "deposit rate in advance" (Wei, 155-72) can be discussed, regarding China's financial reform.

a) Loan Rate in Advance: This policy option is favored by most Chinese banks and Chinese economists. The loan rate in advance policy could indirectly bring significant negative results upon the average household's standard of living. As stated earlier, most firms in china are highly elastic in their demand for rentable funds in relation to interest rate fluctuations; moreover, households have shown a tendency to be highly inelastic with regard to savings and expectation of inflation. As a result, it is conceivable to expect a scenario of rising interest rates, of rising commodity prices, and a rise in consumer prices and inflation. In addition to reduction of disposable income as deposits, any liberalization of loan lending standards that would result in higher interest rates would likely lead to a solvency crisis for many enterprises. (Pettis, 1011)

b) Deposit Rate in Advance: This policy option is the most beneficial for the enterprise - by avoiding the loan in advance liberalization, the enterprise is given time to adjust internal controls to pending reforms without the pressure of rising interest expense or potential loss of access to rentable funds.

Altogether, the conditions for interest rate liberalization do not exist yet, and although some measures of liberalization may proceed with great benefits and with relative ease, the policy makers must realize that liberalization is a tailored response to the financial system. The strength and stability of China's state and commercial banks will continue to determine the speed with which the interest rate liberalization is adopted. Moreover, further liberalization cannot proceed safely without assertion that the traditional responses to interest rate adjustments are allowed to ensue. The following general conditions must be met for full interest rate liberalization to exist. (World Bank, 1996; Wei, 117)

- $\quad$ Alternatives to bank deposits must be made widely available

- $\quad$ Savings must be elastic in response to inflation expectations and changes in deposit rates

- Investment must be elastic to expected returns vs. expected risks

- $\quad$ Bank activity - horizontal and vertical - must be regulated and supervised.

\section{Intermediation Of Public, Private, And Foreign Investment}

This section will explore China's current standards of investment intermediation to examine the state's effectiveness in promoting the three objectives of the liberalization of public, private, and foreign investment. 


\section{China's Investment Level}

Identifying the factors behind China's attractiveness to investment, the sources of investment, and the multitude of those flows, is a pivotal step toward comprehending how China must shape its reforms to endure the anticipated fluctuations that will occur.

a) Competitive Advantage: The Magnet for Investment: Currently, over 100 million people migrate among China's metropolises in search of employment. (People's Daily, 20 December 2003) The scope of available labor is both a great competitive advantage as well as a great source of concern for public officials, private and foreign investors alike. The state and the PBC face the difficult task of continuing to provide investment incentives, to ratify financial liberalization, and to absorb the fallout - the unemployed - of the transition.

The other magnet for investment - both domestic and foreign - is the highly anticipated potential locked away in China's domestic consumer markets. For many current China's trading partners, the acceptance of China into the World Trade Organization was seen as the most significant indication of the rising flood of consumer demand. A broadening of the Chinese consumer demand will serve as a stabilizing factor of internal drive. (Chow, 2003)

b) Sources and Magnitude of Investment: Data published by the National Bureau of Statistics of China (NBSC) for the year 2002, breaks down the sources of investment, their magnitude, growth rate - year after year - and the proportion of total investment:

\begin{tabular}{|c|c|c|c|}
\hline & Investment & Growth Rate & Proportion \\
\hline Total Sources of funds (Billions) & $2,691.42$ & 28.6 & 100.00 \\
\hline State Budgets & 194.38 & 41.6 & 7.20 \\
\hline Domestic Loans & 615.81 & 30.4 & 22.90 \\
\hline Bonds & 15.42 & 34.1 & .60 \\
\hline Foreign Investment & 140.65 & 23.0 & 5.20 \\
\hline Of which: FDI & 96.02 & 35.2 & 3.60 \\
\hline Self-Raised Funds & $1,239.05$ & 26.5 & 46.00 \\
\hline Of which: Enterprise & 788.34 & 27.2 & 29.30 \\
\hline Of which: Issuing of Stocks & 9.50 & 3.4 & .40 \\
\hline Others & 486.12 & 28.6 & 18.10 \\
\hline Foreign Direct Investment (2001) & 44.04 & --- & 3.80 \\
\hline
\end{tabular}

(UNDP: HDR 2003, $288 \& 300$ )

Of particular interest is the inflow of foreign direct investment (FDI), an often cited driver of China's economic growth. At first glance, one might not consider a mere 3.8 percent (2001) and 3.6 percent (2002) share of annual investment to be of any significance to China's economic health. However, "foreign invested enterprises (FIE) in China contributed nearly 20 percent to China's gross industrial output and about 41 percent of exports in 1995 to 1996. By October 2002, FIE had generated 23 million of labor employment, about 10 percent of total labor employment in urban areas." (Chow, 2003)

Ultimately, the source of investment capital - or, rather, its use - is decided by the state. (Dorn, 2002) An integral part of attracting investment for the future is the disclosure or indication of a roadmap for future capital account liberalization strategy. While the leadership in China has discussed its areas of interest with respect to FSR and capital account liberalization, no roadmap has yet been revealed. However, these areas of interest do fit within the traditional pattern of liberalization as determined by the IMF. 
China is still in the infant stages of the liberalization of FDI inflows, as foreign investment can only be utilized in export-only exclusive enterprise, joint partnership enterprise, contracted operations, or cooperative developments. (NBSC: National Account, 2002) Recent legal reforms, enacted with the overwhelming support of the National People's Congress in its amendment to the 1982 constitution in March of 2004, recognize that "a citizen's lawful private property is inviolable" - an unprecedented acknowledgement of the right to personal property. (BBC News, 2004) In addition, the PBC has allowed non-financial institutions - like the Shanghai and Shenzhen Stock Exchanges - to further extend the financial system's depth and mechanism for raising capital. As of 2002, the Shanghai Stock Exchange has reported 35,556,500 investor accounts - 181,000 of these were institutional investor account. (Shanghai Stock Exchange, 2004)

Despite being backed by the local governments, in several instances, theft, fraud and mismanagement of the funds and the projects have cost foreign investors hundreds of millions of USD. (Miller, 2003) Such incidents would hamper the flow and the magnitude of future FDIs, which underscore the importance of further legal frameworks and reforms that provide safety to investors. Future consideration of sovereign and project risk could make foreign investment or FDI economically unfeasible - seriously harming China's ability to move forward with enterprise and financial reforms.

\section{Investment Structure}

Political policy has shaped how and what economic projects receive investment. In 2004, the NBSC released data that shows fixed asset investment, an aggregate that accounted for 97 percent of all investment spending (total investment in fixed assets/total sources of funds $=.9704$ ):

\begin{tabular}{cccc} 
& Investment & Growth Rate & Proportion \\
\hline Total Value of Fixed Asset Inv. & & & \\
1. Capital Construction & $\mathbf{2 6 1 1 . 8 5}$ & $\mathbf{2 3 . 4}$ & $\mathbf{1 0 0 . 0 0}$ \\
Of which: Transportation & 1378.34 & 23.8 & 52.80 \\
Innovation & 18.44 & 20.9 & .70 \\
$\quad$ Real-Est. Dev. & 502.26 & 15.7 & 19.20 \\
Others & $\mathbf{6 2 2 . 8 1}$ & $\mathbf{2 8 . 2}$ & $\mathbf{2 3 . 8 0}$ \\
2. Administrative Relationship: & 108.45 & 30.0 & 4.20 \\
Central Government Project & --- & --- & --- \\
$\quad$ Local Projects & 480.91 & -0.8 & 18.4 \\
3. Type of Construction: & $\mathbf{2 1 3 0 . 9 4}$ & $\mathbf{3 0 . 6}$ & $\mathbf{8 1 . 6 0}$ \\
New Construction & & & --- \\
Expansion & --- & -- & $\mathbf{4 8 . 0 0}$ \\
Reconstruction & $\mathbf{9 5 4 . 3 3}$ & $\mathbf{2 9 . 9}$ & 29.80 \\
\hline
\end{tabular}

* (In Billions)

Of great interest to reformists is the funneling of fixed asset purchases to state-owned enterprise. Stateowned enterprise has increased its investment in fixed assets as a mix of their total asset portfolio - from 36 percent to 44 percent during the period of 1994 to 2000. The decrease in SOE employment share of total employment in China could be related to the purchase of these new, technologically efficient fixed assets - it also fits in with a 1998 directive in which the PBC set the upgrading of SOEs as a priority. However, of great concern is the continued borrowing by industry - apparently for investments in new construction and real-estate development which has resulted in an environment of overinvestment - and evidence of the lack of producer pricing power. (Heytens and Karacadag, 2001) Another concern deals with the investment that occurs at the local government level. Some 
experts may wonder if the government data accurately portrays the full extent of the current investment structure allocated among government, domestic and foreign investors. (Roberts, Business Week, January 19, 2004)

In this respect, there is an apparent breakdown in the informational and supervisory mechanisms within the financial system. Two areas of this breakdown are possible: both the local banks and the credit markets experience little supervision from the state-owned banks with regard to banking relationships with local governments or the PBC has unlinked itself too drastically from the supervision of the Ministry of Finance.

\section{Investment Efficiency}

To grasp the underlying issues in relation to investment efficiency, four different areas need to be explored and examined. This is primarily due to the varying sets of economic actors that take part in the determination of these investment efficiencies.

a) Public Investment: The measurement ratio of investment efficiency, as typical "output over capital input," can prove faulty since ratios are easily manipulated. The survey method (recording of incidents), for the purpose of this research, has proven to be more reliable.

An examination of earlier study by PBC (1987-1989) of 303 public projects demonstrates that the trend of unprofitable management of this sector remains. Of the 303 projects studied, fully one-third were identified as loss-makers. The study also found in a separate sample of 244 industrial projects that even after three years of initializing start-up activities, one-third (81) of these continued to experience negative cash flows, and nearly one-quarter (59) continued to make losses beyond the five year period. Furthermore, seventy-five percent of production capacity and thirty-three percent of investment capital remained under-utilized or unused beyond the same time period. Of the original 303 projects, 287 were found to be operating within soft-budgets - unplanned expenditures accounting for almost one-third of the budget plans. The state, which at one time directly funded these projects out of fiscal budgets, has since divested itself of the responsibility. This action has made the problem of government inefficiency a problem of the financial sector, as state and commercial banks are often prodded by central or local officials to fund these projects. (Wei, 94-95)

With the state-owned industrial complex absorbing nearly seventy-five percent of all investment capital, one may rightly conclude that public investment inefficiency severely hampers China's growth prospects. The central government has experimented with granting greater autonomy to management (laid in the same 1998 effort to update SOEs - as mentioned earlier) in an attempt to stimulate better decision making response time and strategy. The results of this experiment have been devastating due to the cause reform: "asset stripping, de-capitalization, wage manipulation, and tax-evasion." (Broadman, 1999) Perhaps, through the reforming of property rights (as done in March 2004), the rights of the stakeholders management and employees in this case - will be more clearly defined. The clarity of property rights may also serve to eliminate the tendency of enterprise managers to assume that losses are always socialized while profits are privatized - as owners must participate equally in the distribution of gains and losses.

In conclusion, while public investment is quite inefficient, the strengthening of sensible oversight over local management spending and the changes in property rights may provide the pressure for a more clever response to the selection of public investment projects.

b) Foreign Investment: During the past decade, with the exclusion of the United States, China has become the largest recipient of FDI - "accumulating more than $\$ 800$ billion in contractual terms, and $\$ 430$ billion in actual realized terms." (Chow, 2003) Although the growth rate of FDI inflows has slightly decreased during the same period, investors and some economists alike point to these inflows as evidence of foreign investor confidence in the financial sector reforms. (IMF: IFS 2001) Of course, while guessing the logic of investors is a futile pursuit, one can look to the experience of other countries - like those in Latin America - which did not see any correlation between FDI and their implementation of financial sector reforms. (Pettis, 49-50) Evidence from China also suggest that China's inflows of FDI are neither a product of 
reform nor a driving force behind the demand for new capital capacity; rather, the effect of economic and financial sector fragmentation.

Three main reasons - none of which are tied to reform - stand out for the huge inflows of FDI. (Huang, 2001) First, the explicit mandate that disallowed banks from engaging in loan activity with private, exportoriented enterprise efforts to raise capital and then selling the rights to foreign investors - which is accounted for as FDI. Second, the FDI is being used to purchase existing overcapacity - at a discount rather than being used for the purchase of new capital capacity. Third, consumer demands are most easily met by foreign-owned means of production, as domestic firms are altogether inefficient and noncompetitive under the current regulations. Much of this regulation is developed at the local provincial level, since provinces compete to meet the central government growth and tax revenue targets. Provincial governments regularly engage in placing embargos and tariffs on products from foreign provinces - as well as seizing profits made through the sales of goods from other provinces and giving subsidies to firms that rely on local resources. (Wedeman, 2000)

Indeed, the environment for foreign investment is quite favorable and the accumulation of investment is impressive; however, such investment should be construed as evidence of overwhelming optimism for the progress of liberalization or FSR. Financial sector reform and capital control liberalization is done for the benefit of the domestic economy, focusing entirely upon attracting foreign investment (primarily exportdriven investment projects) leaves the long-term health of China's domestic firms - and its financial system - in a weakened state. While in the past, China has successfully relied on FDI inflows to absorb the wave of unemployed workers coming from state-owned enterprise, the basis for relying on FDI, as a long-term policy for growth, is neither wise nor efficient. The PBC and the central government should immediately engage in "restructuring of [its] financial and corporate sectors," (Ishii and Habermeier, 21) by enabling private domestic firms to remain independent through access to capital markets and by eliminating crossprovincial trade barriers and financial restrictions. These measures will ease the inevitable burden to the financial system as financing shifts from FDI to credit markets and tradable debts.

c) Fixed-Asset Investment: As stated earlier, fixed-asset investment swallows over 97 percent of all investment activity - most of which is channeled toward expanding the production of "textiles, iron and steel, construction material, non-ferrous metals and car production." (Hui, 4 September 2003) Investment growth in transportation (cars, planes, ships) was 20.9 percent in 2002, along with growth rate of 28.2 percent in real-estate, 29.9 percent growth in new construction projects, and 20.6 percent growth in reconstruction projects. The only "slow" growing aggregate of construction was that of the "expansion" of the existing production facilities, with only 12.2 percent growth in 2002.

The unused airport and Formula One speedway in Zhuhai are just two documented examples to support this research regarding the overcapacity and waste associated with China's investment in fixed-assets. Investors may take the low inflation statistics as the sign of efficient monetary policy and strong financial wisdom - a picture that is quite contrary to the truth. Moreover, the lack of financial prudence for project risk/return assessment has resulted in a very inefficient use of China's investment capital.

d) Equity-Share Investment: It is important to discuss the efficiency of investment in the context of equityshares listed in Chinese companies. Very little, aside from performance of share prices and various indices, is available to indicate whether or not equity-share investment is indeed efficient. However, recent allegations within the U.S. investor community have provided some material and context for such a measurement. Excessive trading - or "churning" - is a prosecutable offense, one that has been defined as "significantly diminishing shareholder return." (Winslow and Anderson, 1990) Broker trading fees and churning are but one aspect of inefficient management. Another concern is the health of the financial market in which significant volatility inflates the price of the investment unit. 
The Shanghai Stock Exchange in its Fact book: 2002, reports a commission, payable to the securities company, of less than or equal to 0.3 percent of the value of the trade - or, at least, $¥ 5$ RMB (equivalent to $\$ 0.6047$ USD). By comparison, The New York Stock Exchange charges a fixed exchange fee of $1 / 30,000^{\text {th }}$ of a cent per trade. Such relatively high trading fee, serves as an incentive to securities managers (who are mostly employed by the state and commercial banks) to place many more trades than are necessary in order to increase the profit revenue for the bank. The following schedule of turnover within a cross-section of mutual funds will highlight the excessive trading:

\begin{tabular}{lccccc}
\multicolumn{1}{c}{ Category } & $\begin{array}{c}\text { Mean Turnover } \\
\text { Ratio }\end{array}$ & Std. Dev. & 1 SD & 2 SD & 3 SD \\
\hline Aggressive Growth & 1.18 & .72 & 1.90 & 2.62 & 3.35 \\
Balanced & .66 & .58 & 1.23 & 1.81 & 2.38 \\
Equity Income & .70 & .53 & 1.23 & 1.76 & 2.29 \\
Growth & .98 & .61 & 1.58 & 2.19 & 2.80 \\
Growth-Income & .53 & .55 & 1.09 & 1.64 & 2.19 \\
International & .55 & .42 & .96 & 1.38 & 1.79 \\
Option-Income & 1.45 & .74 & 2.19 & 2.93 & 3.67 \\
Small Company & .54 & .39 & .93 & 1.32 & 1.71 \\
Income & .58 & .40 & .98 & 1.39 & 1.79 \\
\hline
\end{tabular}

Winslow, Arthur Donald; Anderson, Seth C. The North Carolina Law Review, Vol. 68, January 1990, Number 2, n. 326-36, pp. 350

Option-income trading is widely recognized as a strategy that involves a greater level of volatility and turnover to its use of derivatives and leverage; in this study, the mean turnover ratio for option-income strategy was 1.45 . The next highest ratio was among those funds that sought "aggressive growth," with a mean turnover ratio of 1.18 .

Based on a poll of twenty most heavily traded companies (by volume), the mix of Shanghai Stock Exchange trading volume fits in the "growth" category - with a mean turnover ratio of 0.98 . In 2002, The Shanghai Stock Exchange Composite (based on the number of tradable shares) experienced a turnover ratio of 2.08 for "A" shares (tradable only by Chinese citizens) and .95 for "B" shares (tradable only by foreigners and some Chinese citizens) - or 208.74 percent and 95.99 percent respectively. (Shanghai Stock Exchange: Fact book 2002) With consideration of China's lack of depth in its financial sector markets (i.e. lack of derivative securities, corporate debt, widely traded public debt, and relatively few listed companies - 759 as of the end of 2002), the turnover ratio of "A" shares is a clear indication of mismanagement and excessive trading by banks on behalf of the stockholders. Those shares ("B" shares) traded by foreigners, appear not to be excessively traded and their ratio to be comparative to the mean U.S. growth share turnover ratio.

In conclusion, one must consider not only the availability of the financial instruments, but also the policies that govern them. In case of equity-share trading by Chinese banks, perhaps the establishment of the Shanghai and Shenzhen exchanges preceded too soon, as the reform of the policies governing the conflict of interest within the financial sector needs to be addressed in order to ensure efficient maximization of future shareholder returns.

\section{Elimination Of The Recurrence Of Non-Performing Loans And The Recapitalization Of Bank Assets}

In 1997, the People's Bank of China estimated that non-performing loans (NPLs), as a percentage of the total bank assets, amounted to 20 percent. Earlier, in July of 1995, the Ministry of Finance, issued a directive which stated the central government's goal to help reduce the incidence of such loans to 15 percent within two years. (Wei, 173) But, it did not happen. In May of 2001, the Bank of China announced that as of the end of 2000, the BOC's non-performing loans totaled 28.8 percent of total bank assets. This revelation comes only after a previous transfer 
in 1999 of non-performing loans (accounting for another 8 percent of BOC's assets) to an asset management company (AMC) of which the BOC now holds an equity stake as replacement for the transfer of NPL classified assets. (Bottelier, 6) As mentioned earlier, in January of 2004, the BOC was also the recipient of a $\$ 45$ billion bailout by the $\mathrm{PBC}$ - all in an attempt to prepare the BOC for a public offering and, presumably, the BOC's proceeds will go toward further NPL writ-offs.

Despite its troubles with NPLs, the BOC is China's third largest and most prosperous bank. The obvious question would be "what about the rest?"

The examination of the following two areas will provide a better understanding of non-performing loans:

\section{Ensuring the non-recurrence of non-performing loans through policy reform}

Many reasons can be identifies for NPLs: the use of policy loans, high enterprise debt and poor riskportfolio management. Of particular interest, however, is the latter, risk-portfolio management, the reason for it, and how to improve the management function. The poor decision making can partly be blamed on government directed lending policy; however, as the frequency of "forced decision-making" diminishes, the primary culprit becomes "asymmetric information."

Asymmetric information is the condition in which two actors (in this case, the lender and the borrower) do not share identical information regarding a mutual decision. Feng Wei identified three negative consequences of asymmetric information in the financial sector. First, it impedes the price function of the interest rate; second, it often leads to adverse loan selection; and third, it increases the cost of monitoring and enforcing loan contracts (e.g. legal expense). (Wei, 146-8)

Its current policy, gives the PBC the power of bank supervision over the approval of the establishment, functional alteration, and permanent termination of a banking institution; right to audit, control, or supervise all deposits, credits, and settlements; and, the raising or lowering of deposit and loan rates. (Wei, 150) Given these controls and the established mechanism for communication between the PBC and state and commercial banks, the discrepancies in informational content within this system do not account for the high rate of NPL incurrence.

The only other exchange of information within the system happens between the borrower and the lender asymmetry occurring primarily as a result of differing accounting standards and/or lack of ethics. A firm's assets, while distinguished as either inventory or raw materials, are not classified as un-sellable, year-old inventory, or a product scheduled for shipment. All "Assets" are valued at market prices, "regardless of whether they are sold or paid for, as classified as current assets... Furthermore, both inventories and receivables are credited as revenues in the income statement and included in profits, even though neither of them generates cash." (Heytens and Karacadag, 5) In light of this documentation, the probability that asymmetric information enters the information flow at the exchange between the borrower and the lender is very high.

This calls for a set of standard accounting principles and the empowerment of state and commercial banks to adjust their lending models according to what information they receive. One desirable outcome of a liberalized financial system is its ability to serve economic actors of any financial condition. China's current method of lending is very precarious - approval or decline - allowing the lending institution only a fifty percent hedge against an adverse loan decision. Dynamic financial systems, almost always, allow for some level of approval (i.e. lending less than the requested loan amount, granting secured and collateral loans, and varying rents for assumed risk). These tools allow a lender to mitigate even the highest levels of risk to a more acceptable level of risk. Therefore, China should develop policy and financial instruments whereby banks may practice "price-discovery" or the screening of risk. (Ishii and Hambermeier, 32) 


\section{Methods for Recapitalizing Bank Assets Classified as Non-performing Loans}

The decision of how best to dispose of non-performing loan assets, while maintaining bank solvency and fiscal discipline is best explained by examining the three variable options and their cost/benefit to the central government, the bank, and the enterprise.

a) Debt writing off - "debt Cancellation": By far, the least complex method of dealing with NPLs is to eliminate NPLs as both an asset to the bank or a liability to the enterprise. The central government's fiscal position does not change; however, if the proportion of NPLs is significant, bank asset elimination could result in bank insolvency and failure, at which point, the cost of "bailout" to the central government is evident, but not known. (Wei, 198)

b) Debt Equity Swap - "Debt Equalization": Basically, this option would result in the bank taking an equity stake in the enterprise. The enterprise re-classifies the liability as a minority stake - or according to the magnitude of balance, surrenders control of the enterprise to the bank while remaining a minority stake. Once again, the fiscal condition of the central government does not change. In this instance, the question is: which is better? Owning a bad loan or a bad company? To which, the answer is "neither." The only prospect a bank has in this situation is the potential that it can redirect management decisions toward a more profitable end; however, such action would incur additional costs and requires expertise in industry. (Wei, 198-9)

c) Debt bond Swap - "Debt Socialization": This option replaces the NPL assets of banks with credit assets backed by the central government. In exchange, for its recapitalization of the bank, the central government then assumes an equal equity stake in the enterprise. The enterprise eliminates the bank liability and reclassifies it as a minority/majority stake controlled by the central government. The debt-bond swap ensures the solvency and stability of the financial system - a priority of reform; however, it incurs a higher probability of future fiscal deficits as loss-making enterprises are nationalized (made property of the state). Nonetheless, financial stability is far more costly to repair than a failing enterprise; therefore, this option is favored as a means of recapitalizing bank portfolios.

\section{CONCLUSIONS}

Providing the evidence of China's progress toward financial sector reform - its successes, failures, advantages, and barriers - as specified in this paper, one should maintain an open assessment of such factors as FSR and the desired extent of the FSR. China is a case study in growth management, the outcome of which is still uncertain; whether China can continue to manage for growth within a non-democratic, globally integrated environment is also uncertain. Lessons from "big-bang" reform in Russia have definitely played a part in controlling the speed with which reforms are implemented. However, amid the rise and fall of FSR's speed, the world would patiently hold its collective breath.

\section{BIBLIOGRAPHY}

1. Aziz, Jahangir; Duenwald, Christoph. IMF Working Paper: Growth-Financial Intermediation Nexus in China. Working paper \#02/194. November 2002.

2. BBC News. China Endorses Private Property. Published: 15 March 2004. Accessed Via Internet: 27 April 2004. http://news.bbc.co.uk/go/pr/fr/-/I/hi/world/asia pacific/3509850.stm.

3. Bottelier, Pieter. China's Domestic Debts Conference paper, Financial Sector Reform, in China. John F. Kennedy School of Government, Harvard University. 11-13 September 2001.

4. Broadman, Harry G. IMF: Finance \& Development: The Chinese State as Corporate Shareholder. September 1999. Volume 36, Number 3.

5. Chow, Peter C.Y. Journal of Asian and African Studies: China's Sustainable Development in Global Perspective. 01 December 2003. 
6. Cooper, James C; Madigan, Kathleen. Business Week: One More Rate Cut.. Published: 21 January 2002. Accessed via Internet: 27 April 2004. http://www.keepmedia.comljsp/article detail_print.jsp.

7. Dorn, James A. Chinaonline: Liberalizing China's Financial Sector. Published: 06 December 2002. Accessed via Internet: 19 March 2004.

8. Feltenstein, Andrew; Nsouli, Saleh M. IMF Working Paper; Big Bang Versus Gradualism in Economic Reforms: An Intertemporal Analysis with an Application to China. Working paper \# 01/98. August 200 I.

9. Gregory, Neil; Tenev, Stoyan. IMF: Finance \& Development: The Financing of Private Enterprise in China. March 2001, Volume 38, Number 1. Accessed via Internet: 10 January 2004.

10. Hey tens, Paul; Karacadag, Cern. IMF Working Paper: An Attempt to Profile the Finances of China's Enterprise Sector. Working paper \# 01/182. November 2001.

11. Huang, Yasheng. Economic Fragmentation and FDI in China. Working Paper \#374. Harvard Business School. May 200 I.

12. IMF (International Monetary Fund). International Financial Statistics. Washington, Of September 200 I.

13. IMF (International Monetary Fund). IMF Concludes 2003 Article IV Consultation... Public Information Notice No. 03/136. 18 November 2003. Accessed via Internet: to January 2004. http://www.imf.org

14. IMF (International Monetary Fund). International Financial Statistics. Washington, DC March 2004. pp. $278-281$.

15. Ishii, Shogo; Habermeier, Karl; etal. IMF Occasional Paper: Capital Account Liberalization and Financial Sector Stability. Occasional paper \#211. Washington, DC. 2002.

16. Kwok, K.C; Hui, Tai. China Snapshot. Publish dates: 20 March 2002; to July 2002; 13 January 2003 ; 04 September 2003. Accessed via Internet: 10 April 2004. http://globalmarkets.standardchartered.comltreasury/common/index $\sim$ r.

17. Lardy, Nicholas R. China's Unfinished Economic Revolution. Brookings Institution Press. Washington DC. 1998.

18. Mathieu, Nicolas. World Bank/OED Sector Report: Financial Sector Reform: A Review of World Bank Assistance. Report No. 17454. March 1998. Accessed via Internet: to January 2004. http://www.worldbank.org/html/oed.

19. Miller, Matthew; Clifford, Mark L. BusinessWeek: Losing Millions in Zhuhai. 01 I December 2003. pp. 48.

20. National Bureau of Statistics of China (NBSC). National Accounts. 19 April 2002.

21. People's Daily. GDP No Longer Sole Index of China's Growth. Published: 20 December 2003. Accessed via Internet: 23 December 2003. http://www.english.peopledaily.com.cn/2003 12120/eng20031220 130853.shtml.

22. Pettis, Michael. The Volatility Machine: Emerging Economies and the Threat of Financial Collapse. Oxford University Press. New York, NY. 2001.

23. Roberts, Dexter; et, al. Business Week: Overhauling China Inc.? 25 August 1997.

24. $\quad$ Roberts, Dexter; et, al. Business Week: Worrying About China. 19 January 2004. pp 28.

25. Ross, Lester. International Financial Law Review: Why China's Regulations Are Stalling Foreign Banks. April 2002. Vol. 21, Iss. 4, pp. 55. Accessed via Internet: 20 March 2004. http://proquestumi.com

26. Shanghai Stock Exchange (SSE). Factbook: 2002. Accessed via Internet: 10 January 2004. http://www.sse.com.cn.

27. United Nations Development Programme. Human Development Report: 2003. Oxford University Press. New York. 2003.

28. Warner, Jeremy. The Independent: Outlook: Why the World's Economy is Stuck. Published: 24 January 2004. Accessed via Internet: to April 2004. http://www.highbeam.com/library/doc3.asp?DOCID= I G I: 112499681 \&print:

29. Wedeman, Andrew. Bamboo Walls and Brick Ramparts: Rent Seeking, Local Protectionism, and Marketization in China. 2000.

30. Wei, Feng. China's Financial Sector Reform in the Transition to a Market Economv: Kev Issues and Policy Options. Lit Verlag MUnster, London. 1999.

31. Winslow, Donald Arthur; Anderson, Seth C. The North Carolina Law Review. "A Model for Determining the Excessive Trading Element in Churning Claims. January 1990. Vol. 68, Number 2. pp. 326-361. 
International Business \& Economics Research Journal - October 2007

Volume 6, Number 10

NOTES 